\author{
Witold N. NowAK, IzABElla Noworyta, GrZEgORZ SOKOŁOWski, \\ ALICJA JÓZKOWICZ
}

Zakład Biotechnologii Medycznej

Wydziat Biochemii Biofizyki i Biotechnologii

Uniwersytet Jagielloński $w$ Krakowie

Gronostajowa 7, 30-387 Kraków

Email:alicja.jozkowicz@uj.edu.pl

\title{
MYSZY HUMANIZOWANE - ZASTOSOWANIE DO MODELOWANIA CHORÓB ZAKAŹNYCH
}

\section{WPROWADZENIE}

Poznanie biologicznych podstaw fizjologii człowieka nie byłoby możliwe bez badań na zwierzętach laboratoryjnych. Mimo ogromnych możliwości jakie zapewniaja hodowle komórek prowadzone in vitro, a zwłaszcza hodowle organoidów, doświadczenia na zwierzętach są wciąż niezbędne dla zrozumienia patofizjologii chorób i bardzo pomocne przy opracowywaniu nowych leków. W badaniach biomedycznych najczęściej wykorzystywane sa myszy i szczury. Wybór gryzoni jako organizmów modelowych wynika $z$ jednej strony $z$ ich genetycznego i fizjologicznego podobieństwa do ludzi, a $z$ drugiej, $z$ ich małych rozmiarów, łatwości hodowli, dużej płodności i niewielkich kosztów utrzymania. Szczególnie cennym gatunkiem stały się myszy, zwłaszcza po opracowaniu metod precyzyjnego wprowadzania modyfikacji genetycznych i tworzenia zwierząt transgenicznych (BRYDA 2013).

Analiza porównawcza ludzkiego genomu zsekwencjonowanego w 2001 r. (LANDER i współaut. 2001, VENTER i współaut. 2001) oraz genomu myszy zsekwencjonowanego w 2002 r. (WATERSTON i współaut. 2002) wykazała, że oba gatunki maja ponad 95\% wspólnych genów. Dlatego wiele badań prowadzonych na mysich modelach dobrze thumaczy zarówno biologie myszy, jak i człowieka (BRYDA 2013). Należy jednak pamiętać, że mimo podobieństwa genetycznego, fizjologia myszy i ludzi $\mathrm{w}$ wielu ważnych aspektach jest jednak odmienna. Dotyczy to np. tempa metabolizmu, gospodarki lipidowej, wrażliwości na uszkodzenia DNA, podatności na rozwój nowotworów, czy możliwości produkcji endogennego kwasu askorbinowego. To sprawia, że wyniki uzyskane na modelach mysich nie zawsze można odnosić bezpośrednio do ludzi.

Szczególnie istotne $z$ punktu widzenia wykorzystywania myszy do badań biomedycznych sa różnice dotyczące układu odpornościowego i hematopoezy. Układy odpornościowe ludzi i myszy, mimo wspólnych podstawowych zasad działania, wykazuja cechy specyficzne dla gatunku zarówno w odporności wrodzonej, jak i nabytej. Niektóre odmienności łatwo zauważyć już przy podstawowej analizie hematopoezy i parametrów hematologicznych. U zdrowych dorosłych ludzi hematopoeza zachodzi prawie wyłacznie w szpiku kostnym, a największy procentowy udział wśród leukocytów krwi maja granulocyty. U zdrowych, dorosłych myszy hematopoeza jest aktywna i w szpiku i w śledzionie, a dominująca populacja krążących leukocytów sa limfocyty. Inne różnice wymagaja dokładniejszych analiz. Specyficzne dla gatunku sa np. ważne białka regulujące hematopoezę, jak choćby Sca-1 (ang. stem cell antigen-1, Ly6a). Odmienna jest również regulacja ekspresji genów kodujących białka biorace udział w reakcji na infekcje. Dotyczy to między innymi działania i lokalizacji receptorów typu Toll (ang. toll-like receptors, TLR2, TLR3, TLR9 i TLR10), rodzaju komórek produkujacych defensyny czy aktywno- 
A

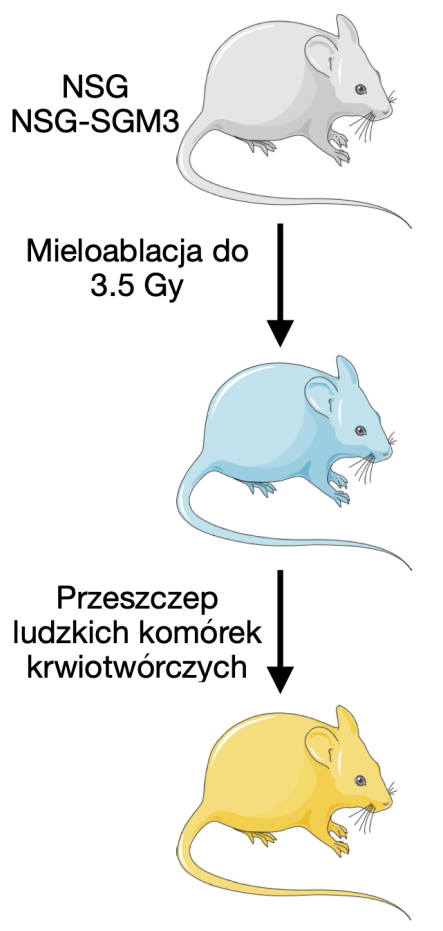

B

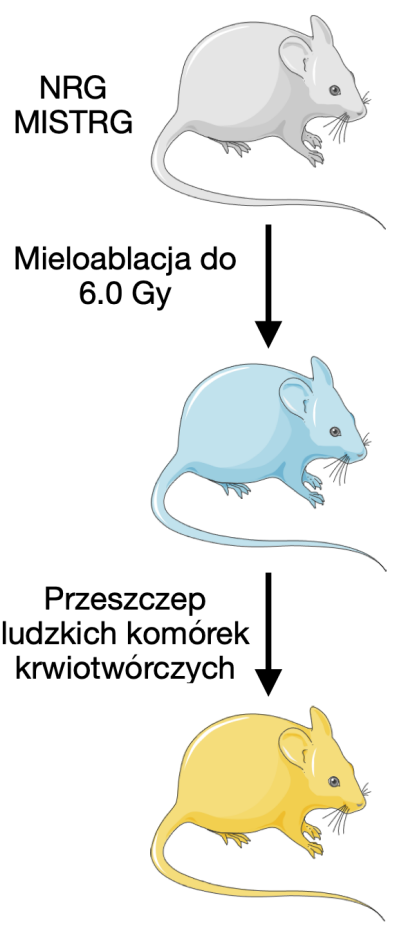

C

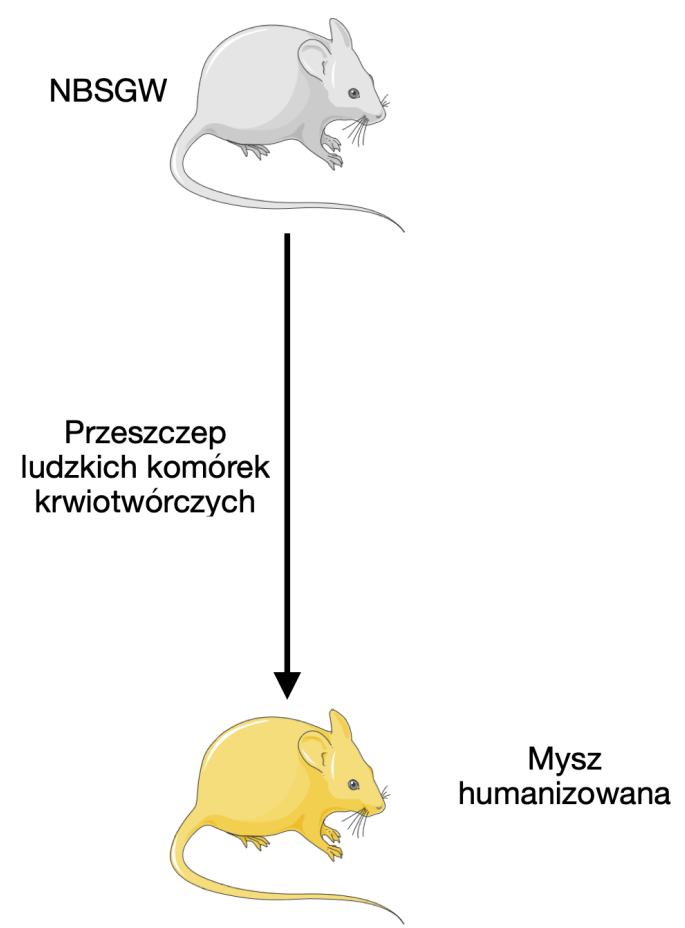

Ryc 1. Procedura humanizacji myszy NSG i NSG-SGM3 wymaga przed przeszczepieniem ludzkich komórek krwiotwórczych zastosowania mieloablacji za pomoca niskich dawek promieniowania jonizującego - do 3,5 Gy (A), myszy NRG i MISTRG sa bardziej odporne na promieniowanie jonizujace i moga być traktowane dawka promieniowania do 6 Gy (B), myszy NBSGW nie wymagaja mieloablacji przed przeszczepieniem ludzkich komórek krwiotwórczych (C). Rycinę przygotowano wykorzystując Servier Medical Art.

ści niektórych cytokin, np. interleukiny 4 (ang. interleukin 4, IL-4) czy interleukiny-13 (IL-13) (podsumowane w MESTAS i HuGHES 2004).

Dodatkowe przeszkody pojawiają się przy próbach wykorzystywania myszy w badaniach zwiazanych $z$ chorobami infekcyjnymi, część patogenów może bowiem infekować jedynie komórki ludzkie. Do takich patogenów należa między innymi: pałeczka duru brzusznego Salmonella typhi, krętek odkleszczowej goraczki powrotnej Borrelia hermsii i prątek gruźlicy Mycobacterium tuberculosis (DOUAM i Ploss 2018) oraz wirus ludzkiego niedoboru odporności (ang. human immunodeficiency virus, HIV), wirus cytomegalii (ang. cytomegalovirus, CMV), wirus Epsteina-Barra (ang. Epstein-Barr virus, EBV) mogacy wywoływać mononukleozę zakaźną, ludzki wirus T-limfotropowy (ang. human T-lymphotropic virus, HTLV) mogacy wywołać białaczki i chłoniaki z limfocytów T czy też wirus mięsaka Kaposiego (ang. Kaposi's sarcoma-associated herpesvirus, KSHV). Takim patogenem okazał się również wirus SARS-CoV-2 wywołujący COVID-19.

Sposobem na obejście tych przeszkód jest wykorzystanie myszy humanizowanych (Ryc. 1). Termin „myszy humanizowane” nie jest precyzyjny i może być rozumiany szeroko. W najbardziej ogólnym ujęciu humanizacja myszy polega albo na wprowadzeniu takich modyfikacji genetycznych, które upodabniają fizjologię mysia do fizjologii ludzkiej (np. wyłączenie możliwości edycji mRNA dla apolipoproteiny B w mysich hepatocytach likwiduje jedną $z$ różnic $w$ metabolizmie lipoprotein) albo na przeszczepieniu myszom ludzkich komórek i tkanek (a nawet mikrobiomu), które po przeszczepieniu zachowuja swoje funkcje specyficzne gatunkowo. Oba podejścia sa często stosowane łacznie. Uzyskane modele myszy humanizowanych (ang. humanized mice, humice) staja się niezastapionym narzędziem $\mathrm{w}$ badaniach patogenezy ludzkich chorób nowotworowych, autoimmunizacyjnych i infekcyjnych. Pozwalają również na przedkliniczna ocenę skuteczności proponowanych terapii, także takich, któ- 
Tabela 1. Słowniczek.

\begin{tabular}{|c|c|}
\hline Komórki progenitorowe & $\begin{array}{l}\text { Komórki potomne pochodzące od komórek macierzystych, sa zazwyczaj bardziej } \\
\text { ukierunkowane i nie mają zdolności samoodnowy }\end{array}$ \\
\hline Mieloablacja & Zniszczenie szpiku kostnego przez radioterapię lub chemioterapię \\
\hline Mielopoeza & $\begin{array}{l}\text { Wytwarzanie limfocytów linii mieloidalnej tj. granulocytów (neutrofili, bazofili i } \\
\text { eozynofili), monocytów }\end{array}$ \\
\hline Myszy permisywne & Myszy w których możliwa jest infekcja i namnażanie specyficznego wirusa \\
\hline Nisza hematopoetyczna & $\begin{array}{l}\text { Środowisko szpiku kostnego, w którym występują krwiotwórcze komórki macie- } \\
\text { rzyste. Niszę tworza komórki kości, naczyń krwionośnych, tkanki łącznej, w tym } \\
\text { komórki macierzyste zrębu szpiku kostnego. Sygnały pochodzące z niszy są klu- } \\
\text { czowym regulatorem stanu komórek krwiotwórczych. }\end{array}$ \\
\hline Rekombinacja V(D)J & $\begin{array}{l}\text { Proces tworzenia genów przeciwciał lub receptorów limfocytów } \mathrm{T} \text { poprzez rekom- } \\
\text { binację. Przeciwciała kodowane sa w genomie przez geny stałe C oraz zmienne V, } \\
\mathrm{D} \text {, J, których występuje kilkadziesiąt wariantów. W procesie rekombinacji docho- } \\
\text { dzi do losowego łączenia wariantów przy udziale kompleksu rekombinazy. }\end{array}$ \\
\hline Transdukcja & Wprowadzenie do komórek RNA lub DNA za pomoca wektorów wirusowych \\
\hline Transfekcja & Wprowadzenie do komórek RNA lub DNA \\
\hline
\end{tabular}

rych działanie wykorzystuje specyficzne cechy ludzkiego układu odpornościowego. Modele te sa obecnie bardzo intensywnie rozwijane, dlatego warto podsumować informacje dotyczace najważniejszych humanizowanych szczepów mysich. Skupimy się na szczepach wykorzystywanych w badaniach nad chorobami wirusowymi, w szczególności nad zakażeniem wirusem SARS-CoV-2.

Informacje dotyczace użytych w pracy terminów znajdzie czytelnik w Tabeli 1.

\section{HUMANIZACJA MYSZY Z NIEDOBORAMI ODPORNOŚCI}

Myszy humanizowane najszerzej wykorzystywane $\mathrm{w}$ badaniach to myszy $\mathrm{z}$ ludzkim układem odpornościowym. Powstaja one na bazie szczepów $z$ niedoborami odporności, często sa też dodatkowo modyfikowane genetycznie, dzięki czemu produkuja ludzkie czynniki stymulujace wzrost komórek krwiotwórczych. Kluczowa jest zwłaszcza produkcja czynników, których mysie formy nie sa rozpoznawane przez ludzkie receptory. Tak dzieje się w przypadku interleukiny 3 (IL-3), czynnika stymulujacego kolonie makrofagów (ang. macrophage colony stimulating factor, M-CSF, CSF1), czynnika stymulujaccego kolonie granulocytów i makrofagów (ang. granulocyte-macrophage colony stimulating factor, GM-CSF, CSF2), trombopoetyny (ang. thrombopoietin, TPO) oraz interleukiny 15 (IL-15), koniecznej dla prawidłowego rozwoju komórek NK. Częściowa interakcja między mysimi ligandami a ludzkimi receptorami zachodzi natomiast w przypadku czynnika wzrostu komórek macierzystych (ang. stem cell factor, SCF, KITL), liganda receptorowej kinazy tyrozynowej FLT3 (ang. FMS-like tyrosine kinase 3 ligand, FLT3L) i interleukiny 7 (IL-7).

Najlepiej będzie, jeśli produkcja ludzkich białek w humanizowanych myszach nie zachodzi konstytutywnie, ale jest regulowana analogicznie, jak w mysiej hematopoezie. Można to uzyskać wprowadzajacc ludzkie geny w miejsce ich mysich odpowiedników, pod kontrola endogennych promotorów. Dzięki takim modyfikacjom nisza hematopoetyczna promuje ludzka hematopoezę po przeszczepieniu ludzkich krwiotwórczych komórek macierzystych i progenitorowych.

Myszy $z$ niedoborami odporności sa podstawa tworzenia wszystkich modeli doświadczalnych, wykorzystujących przeszczepienia ksenogeniczne. W wielu badaniach, w których konieczne jest podanie myszom komórek ludzkich (np. komórek nowotworowych), używa się szczepów nude (Foxn $\left.1^{\text {nu}}\right)$, scid, scid-beige lub NOD-scid. Szczepy te maja mutacje powodujace przede wszystkim zaburzenia dojrzewania limfocytów i przez to wykazuja upośledzona odporność. Zostały dobrze scharakteryzowane $\mathrm{w}$ pracy Pauliny KowALCZYK i współaut. (2019), do której warto sięnać. Do tworzenia myszy humanizowanych stosuje się zwykle bardziej zaawansowane szczepy, takie jak NSG lub NSG-SGM3 oraz ich dalsze, wcią̇ udoskonalane modyfikacje. 


\section{MYSZY NSG}

Myszy NSG (szczep NOD.Cg-Prkdc ${ }^{\text {scid- }}$ $-I l 2 \mathrm{rg}^{\mathrm{tm} / \mathrm{W} \mathrm{j} / \mathrm{nul})}$ to szczep wyprowadzony $\mathrm{z}$ nieotyłych cukrzycowych myszy NOD (ang. non-obese diabetic), uzyskanych w latach 70. w Japonii (MAKINO i współaut. 1980). Myszy NOD wykazuja zaburzony rozwój makrofagów i osłabiona aktywność komórek NK i NKT. Nie maja również białka C5 układu dopełniacza (KowALCZYK i współaut. 2019).

Co ciekawe, u wszystkich myszy wywodzących się ze szczepów NOD występuje wariant polimorficzny genu Sirpa, umożliwiajacy efektywne wiazanie receptora SIRP-a na mysich makrofagach do ludzkiego białka błonowego CD47 (będacego również receptorem dla trombospondyny 1). Interakcja bialek SIRP-a/CD47 to sygnal "nie jedz mnie" dla makrofagów, chroniący komórki $\mathrm{CD} 47^{+}$ przed fagocytoza i zwiększający przeżywalność przeszczepionych komórek ludzkich, a co za tym idzie poprawiajacy zasiedlanie szpiku przez przeszczepione krwiotwórcze komórki macierzyste (TAKENAKA i współaut. 2007).

U myszy NSG obecna jest także mutacja scid w genie Prkdc kodujacym podjednostke katalityczna kinazy białkowej zależnej od DNA (ang. DNA-dependent protein kinase, catalytic subunit, DNA-PKcs) oraz mutacja lub delecja genu $I l 2 \mathrm{rg}$ kodującego łańcuch $\gamma$ receptora interleukiny 2 (ang. interleukin 2 receptor subunit gamma). Ma to bardzo ważne konsekwencje, gdyż łańcuch $\gamma$ wchodzi w skład kilku receptorów, nie tylko dla IL-2, ale również IL-4, IL-7, IL-9, IL-15 i IL21. Myszy NSG z delecja genu Il2rg zostały opisane w 2005 r. przez ISHIKAWE i współaut. (2005) oraz SHULTZA i współaut. (2005).

Unieczynnienie genu Prkdc prowadzi do silnej limfopenii, czyli braku funkcjonalnych limfocytów B i T (KOWALCZYK i współaut. 2019), oraz zwiększa wrażliwość myszy NSG na promieniowanie jonizujące. Delecja lub mutacja $I l 2 r g$ wiąże się natomiast $z$ zablokowaniem przekazywania sygnału od interleukin. Wyłączenie aktywności IL-15 blokuje rozwój komórek NK i upośledza odporność nieswoista (KOWALCZYK i współaut. 2019). Dodatkowym skutkiem braku aktywności IL-2 jest zabezpieczenie myszy przed spontanicznym rozwojem chłoniaków.

Myszy NSG maja zatem silnie upośledzona odporność swoista i nieswoista, a jednocześnie ich fagocyty rozpoznaja ludzkie CD47, czyli rozumieja sygnał „nie jedz mnie". Umożliwia to przyjmowanie przez myszy NSG przeszczepów ludzkich krwiotwórczych komórek macierzystych i progenitorowych, w tym także komórek mobilizowanych do krwi obwodowej, a następnie produkcje ludzkich granulocytów, monocytów, limfocy- tów, komórek NK i płytek krwi. Samice myszy NSG uważane sa za najlepszych biorców ludzkich komórek (znacznie lepszych niż samce), skutecznych nawet przy małej liczbie przeszczepianych krwiotwórczych komórek macierzystych. Co istotne, przy zachowaniu warunków zabezpieczających przed infekcjami, myszy NSG żyją i rozmnażaja się normalnie.

\section{MYSZY NRG}

Obecność mutacji scid u myszy NSG powoduje ich zwiększoną wrażliwość na promieniowanie jonizujace stosowane na etapie mieloablacji przed przeszczepieniem ludzkich komórek krwiotwórczych. Myszy szczepu NRG (NOD-Rag1 ${ }^{\text {null-Il2 }}$ rg $^{\text {null) }}$ sa natomiast pozbawione funkcjonalnego genu Rag1 (ang. recombination activating gene 1), co prowadzi do zablokowania rearanżacji V(D)J genów immunoglobulin i receptorów $\mathrm{T}$, a $\mathrm{w}$ konsekwencji do braku funkcjonalnych limfocytów B i T (PEARSON i współaut. 2008). Jest to zatem fenotyp podobny do myszy z mutacja Prkdc scid, ale myszy nie sa tak wrażliwe na promieniowanie jonizujace $(\mathrm{PE}-$ ARSON i współaut. 2008). Co ważne, myszy NRG i NSG wykazuja podobny chimeryzm po przeszczepieniu ludzkich krwiotwórczych komórek macierzystych (PEARSON i współaut. 2008), zapewniajac produkcję ludzkich granulocytów, monocytów, limfocytów, komórek NK i plytek.

\section{MYSZY NBSGW}

Większość szczepów myszy $z$ upośledzonym układem odpornościowym, przed przeszczepieniem ludzkich komórek krwiotwórczych wymaga mieloablacji, często $z$ wykorzystaniem promieniowania jonizującego. Procedura ta jest obciążajaca dla zwierzęcia i niesie wiele skutków ubocznych. Przeszczepienie ludzkich komórek krwiotwórczych do mysich biorców NSG bez uprzedniej mieloablacji jest możliwe, ale mało wydajne.

MCINTOSH i współaut. opublikowali w 2015 r. pracę, w której opisali szczep NBSGW. Sa to myszy NOD, B6.SCID Il2rg null $\mathrm{Kit}^{\mathrm{W} 41 / \mathrm{W} 41}$, które powstały w wyniku skrzyżowania myszy NSG z myszami homozygotycznymi dla zmutowanego genu receptora SCF, czyli KIT $T^{W 1}$. Po przeszczepieniu ludzkich komórek krwiotwórczych bez mieloablacji biorców, poziom chimeryzmu u myszy NBSGW był dziewięć razy wyższy niż chimeryzm u myszy NSG, podobny do chimeryzmu uzyskiwanego u myszy NSG po mieloablacji promieniowaniem jonizującym (MCINTOSH i współaut. 2015). Potwierdzono również, że przeszczepione do myszy NBSGW ludzkie krwiotwórcze komórki macierzyste moga odbudowywać hematopoezę u drugorzędowych 
biorców, co potwierdza ich pełną funkcjonalność. Niemniej, podobnie jak w innych modelach mysich, również u myszy NBSGW przy różnicowaniu ludzkich komórek hematopoetycznych obserwuje się nietypowe dla ludzi ukierunkowanie: zamiast klasycznych proporcji ok. 53\% granulocytów, 20\% limfocytów T i 33\% limfocytów B, uzyskuje się np. 2,5\% granulocytów, 3,3\% limfocytów $\mathrm{T}$ i $68 \%$ limfocytów B.

\section{MYSZY NSG-SGM3 I MISTRG}

Obecność mutacji upośledzających działanie układu odpornościowego umożliwia przyjmowanie przez biorców NSG przeszczepów ludzkich krwiotwórczych komórek macierzystych. Aby poprawić warunki funkcjonowania przeszczepionych komórek i zwiększyć poziom chimeryzmu, wykonano kolejna modyfikację - do mysiego genomu wprowadzono geny kodujace trzy ludzkie białka promujace hematopoeze: SCF, GM-CSF i IL-3 (czyli zestaw białek SGM3).

Geny te zostały po raz pierwszy wprowadzone do myszy NOD-Prkdc scid pod kontrola promotora ludzkiego wirusa CMV w 2003 r. przez NiCOLINIEGo i współaut., a uzyskane myszy charakteryzowały się wysokim stężeniem wszystkich ludzkich białek (na poziomie $\mathrm{ng} / \mathrm{ml}$ ). Aby zweryfikować funkcjonalna skuteczność wykonanej modyfikacji, porównano wydajność przeszczepienia ludzkich płodowych krwiotwórczych komórek macierzystych do biorców wyjściowego szczepu NOD-Prkdcscid oraz biorców szczepu produkujacego ludzkie białka. Zgodnie $z$ oczekiwaniami, u myszy $z$ ekspresją ludzkich genów zaobserwowano zwiększoną ludzka mielopoezę. Jednocześnie jednak stwierdzono zmniejszona erytropoezę i obniżoną produkcję komórek linii limfocytów B (NicOLINI i współaut. 2003). Model nie spełnił więc wszystkich oczekiwań.

W 2011 roku Eva BILLERBECK i współaut. wprowadzili do genomu szczepu NSG geny kodujace ludzkie czynniki wspierajace hematopoezę. Co ciekawe, u uzyskanych w ten sposób myszy NSG-SGM3 również zaobserwowano odbudowę szpiku kostnego $Z$ przeszczepionych ludzkich komórek krwiotwórczych $\mathrm{CD}^{+} 4^{+}$, ale jednocześnie stwierdzono zwiększony udział komórek mieloidalnych w porównaniu do kontrolnych biorców NSG. Większy był również odsetek regulatorowych limfocytów $\mathrm{T} \mathrm{CD}^{+} \mathrm{FoxP}^{+}$(BILLERBECK i współaut. 2011). Warto zwrócić uwagę, że wysoki poziom ludzkich białek IL-3, GM-CSF i SCF u myszy NSG-SGM3 ułatwia także przyjmowanie ludzkich komórek ostrej białaczki szpikowej (ang. acute myeloid leukemia, AML) (WUNDERLICH 2010), co czyni ze szczepu NSG-SGM3 cenny model w badaniach onkologicznych.
Bardzo wyrafinowanym modelem sa myszy szczepu MISTRG. Również one wykazuja znaczne niedobory odporności, które w tym przypadku wynikaja $z$ delecji $I l 2 r g$ i genu Rag2 (ang. recombination activating gene 2), kodującego białko podobne do Rag-2, czyli zaangażowane $\mathrm{w}$ rekombinację $\mathrm{V}(\mathrm{D}) \mathrm{J} \mathrm{w}$ rozwoju limfocytów. Myszy MISTRG wykazuja także ekspresję ludzkich genów kodujących M-CSF, GM-CSF, IL-3 i trombopoetynę, oraz ekspresję ludzkiego genu Sirpa, co ułatwia przyjmowanie się przeszczepów ludzkich komórek krwiotwórczych i stymuluje prawidłowy rozwój ludzkiego układu odpornościowego u mysich biorców (RonGVAUX i współaut. 2014). Co istotne, geny kodujace M-CSF, GM-CSF, IL-3 i trombopoetyne, wprowadzono w miejsce ich mysich odpowiedników.

Myszy MISTRG dobrze wspierają rozwój linii mieloidalnych i komórek NK oraz maja zahamowana aktywność fagocytarna makrofagów w stosunku do przeszczepionych komórek ludzkich. Biorcy, u których endogenne cytokiny sa zastapione ludzkimi odpowiednikami, zapewniaja przewage hematopoezy $z$ wszczepionych komórek ludzkich, kosztem mysiej hematopoezy endogennej. Zapewniaja także różnicowanie ludzkich eozynofili, bazofili i komórek dendrytycznych. Co istotne, wszczepienie ludzkich komórek hematopoetycznych $\mathrm{CD}^{+} 4^{+}$do biorców MISTRG nie wymaga mieloablacji, bo efektywność repopulacji szpiku u biorców nienaświetlanych jest podobnie wysoka jak po mieloablacji. Problemem może być natomiast rozwijająca się u biorców anemia wynikająca z niewystarczajaccej mysiej erytropoezy (RoNGVAUX i współaut. 2014).

\section{MYSZY BLT}

Modyfikacje pozwalające na uzyskanie myszy, w których moga prawidłowo funkcjonować ludzkie krwiotwórcze komórki macierzyste, nie sa jednak wystarczajace w badaniach funkcji komórek efektorowych, zaangażowanych w zwalczanie infekcji. Nie wystarczaja też do badań patogenów, które nie zakażają komórek mysich. Aby badać interakcje między układem odpornościowym a zakażającymi organizm wirusami, konieczny był dalszy rozwój modeli myszy humanizowanych. Wśród nich najlepiej scharakteryzowane sa myszy BLT.

Myszy BLT używane sa m.in. do badań nad wirusem HIV. Ich nazwa pochodzi od przeszczepianych im tkanek: szpiku kostnego (ang. bone marrow), ludzkiej płodowej wattroby (ang. liver) oraz grasicy (ang. thymus) (KARPEL i współaut. 2015). Do tworzenia tego typu myszy wykorzystuje się szczepy NSG, NRG lub rzadziej NOD-scid, którym najpierw przeszczepia się fragment 
ludzkiej watroby i grasicy, a następnie podaje się dożylnie ludzkie komórki krwiotwórcze $\mathrm{CD} 4^{+}$pochodzące najczęściej z ludzkiej płodowej watroby.

Po raz pierwszy model ten został zaproponowany przez LANA i współaut. w 2006 r. Myszy NOD-scid poddane zostały przeszczepowi komórek krwiotwórczych oraz przeszczepowi fragmentów ludzkiej płodowej grasicy i wątroby pod powięź nerkową. Okazało się, że przeszczep grasicy i wattroby płodowej znacząco zwiększa przyjmowanie się komórek krwiotwórczych oraz poprawia rozwój i dojrzewanie limfocytów T (LAN i współaut. 2006). Jest to szczególnie istotne w przypadku wykorzystywania modeli myszy humanizowanych do badań nad zakażeniem wirusem HIV, ze względu na jego tropizm do ludzkich limfocytów T.

\section{OGRANICZENIA MODELI MYSZY HUMANIZOWANYCH}

Wiele modeli myszy humanizowanych powstaje dzięki przeszczepieniu ludzkich komórek krwiotwórczych do szczepów z upośledzonym układem odpornościowym. Przeszczepione ludzkie komórki krwiotwórcze trafiaja jednak do mysiej niszy szpikowej (SzADE i współaut. 2018), która nie w pełni odzwierciedla ludzka niszę, nawet $u$ myszy produkujacych ludzkie cytokiny. Problem ten można częściowo rozwiąać przez utworzenie ektopowych ludzkich nisz dla ludzkich komórek hematopoetycznych. Nisze powstaja po przeszczepieniu ludzkich komórek macierzystych zrębu szpiku kostnego, np. pod skórę myszy (REINISCH i współaut. 2016). Zapewniaja prawidłowe działanie hematopoetycznych komórek macierzystych, potwierdzone zdolnościa do odtwarzania hematopoezy u drugorzędowych biorców. Wciaż jednak śródbłonek współtworzacy ektopowa niszę wywodzi się $z$ komórek mysich. Nie jest jasne, na ile brak ludzkich komórek śródbłonka wpływa na regulację hematopoezy.

Niedawno okazało się, że prawidłowe funkcjonowanie ludzkich komórek odpornościowych u myszy humanizowanych może być zaburzone przez odmienny od ludzkiego mikrobiom myszy, w szczególności u zwierzat utrzymywanych w warunkach wolnych od specyficznych gatunkowo patogenów (ang. specific pathogen-free, SPF) (TAO i REESE 2017). Ten warunek będzie prawdopodobnie coraz częściej uwzględniany w badaniach.

Pojawiają się również przypuszczenia, że funkcja komórek odpornościowych pochodzacych $z$ przeszczepionych komórek krwiotwórczych może zależeć od ich pochodzenia i od historii chorób dawcy. Coraz częściej sugeruje się, że komórki krwiotwórcze posiadaja epigenetyczna „pamięć” przebytych infekcji (CHEN i OzATO 2021). Na razie nie wiadomo jednak na ile może to wpływać na wyniki badań wykorzystujacych myszy humanizowane jako modele chorób zakaźnych.

\section{MODELE ZWIERZECE \\ WYKORZYSTYWANE W BADANIACH NAD SARS-CoV-2}

Pandemia COVID-19 sprawia, że największym zainteresowaniem cieszą się obecnie modele pozwalajace na badanie infekcji wirusem SARS-CoV-2. W badaniach nad SARS-CoV-1, zidentyfikowanym w 2003 r., bardzo przydatne okazały się myszy. Co ciekawe, wirus SARS-CoV-1 infekował myszy typu dzikiego (np. C57BL/6, BALB/c, 129SvEv), ale wywoływał $u$ nich łagodne $i$ nieco inne niż u ludzi objawy, co nie było dobrym modelem sytuacji klinicznej. Dlatego stworzone zostały myszy transgeniczne. Ponieważ SARS-CoV-1 infekuje komórki dzięki interakcji białka S (spike) $z$ białkiem konwertazy angiotensyny-2 (ACE2), stworzono myszy humanizowane, $z$ ludzkim genem ACE2. Były one bardzo wrażliwe na zakażenie, a objawy chorobowe wywoływane przez SARS-Cov-1 były znacznie silniejsze niż u myszy typu dzikiego (ZHENG i współaut. 2021). Myszy te okazały się przydatne również do badań nad SARS-CoV-2 (MUÑOZFONTELA i współaut. 2020).

\section{MYSZY HACE2 I HDPP4}

Podobnie jak SARS-CoV-1, również wirus SARS-CoV-2 wiąże się do ludzkiej konwertazy angiotensyny-2 za pomoca białka S. Jednak w tym przypadku, ze względu na niskie powinowactwo białka $\mathrm{S}$ do mysiej Ace2, klasyczne modele mysie nie moga być wykorzystywane, gdyż myszy typu dzikiego nie sa podatne na infekcje wirusem SARS-CoV-2. Dlatego w badaniach nad COVID-19 wykorzystano modele humanizowanych myszy wykazujacych ekspresję ludzkiego genu $A C E 2$. Istnieja różne warianty takich myszy: $z$ ACE2 pod kontrola promotora keratyny 18 (ang. keratin 18, KRT18) - specyficznego dla komórek nabłonka, $z$ ACE2 pod kontrola promotora $\mathrm{HFH} 4$ (ang. forkhead homologue 4) - specyficznego dla komórek nabłonka płucnego i neuronów, $z$ ACE2 pod kontrolą promotora uniwersalnego (kurzy promotor $\beta$-aktyny $z$ enhancerem CMV) lub ACE2 pod kontrola mysiego promotora genu Ace2 (Muñoz-FonTEla i współaut. 2020). Objawy chorobowe rozwijane przez myszy były silne i w dużej mierze przypominały objawy kliniczne u ludzi. Co jednak ważne, myszy transgeniczne $z$ ekspresja ludzkiego genu 
$A C E 2$ w komórkach $\mathrm{Krt18}^{+}$(Krt18-ACE2), komórkach $\mathrm{HNF}^{+}$(Hnf4-ACE2) lub pod kontrola promotora uniwersalnego rozwijały po infekcji wirusami SARS-CoV zapalenie mózgu, które mogło prowadzić do śmierci zwierząt (DINNON i współaut. 2020, YINDA i współaut. 2021). Objawu takiego nie wykazywały myszy $z$ transgenem $A C E 2$ pod kontrola endogennego promotora Ace2 (MUÑOZFONTELA i współaut. 2020).

Wykorzystujac $\mathrm{w}$ badaniach myszy $\mathrm{z}$ ekspresja ludzkiej konwertazy ACE2 pod kontrola egzogennych promotorów należy pamiętać o zachowanej ekspresji mysiej formy białka. Jest ono nieaktywne w samej infekcji, ale potencjalnie może wpływać na badania skuteczności inhibitorów drobnoczasteczkowych i przeciwciał zakłócających interakcję ludzkiej ACE2 $z$ wirusem.

Myszy, w których mysi Ace2 zastapiono ludzkim genem ACE2, utworzono modyfikując zarodkowe komórki macierzyste myszy C57BL6 lub BALB/c za pomoca Crispr/ Cas9. Zmodyfikowane komórki podano następnie do tetraploidalnych blastocyst (LIU i współaut. 2020). Tetraploidalne komórki moga dać poczatek jedynie tkankom pozazarodkowym (np. łożysku), natomiast zarodki rozwijaja się tylko $z$ podanych zmodyfikowanych diploidalnych embrionalnych komórek macierzystych (Liu i współaut. 2020).

Podobna strategia uzyskania myszy permisywnych dla ludzkich wirusów została zastosowana $\mathrm{w}$ przypadku szczepów wykorzystywanych do modelowania infekcji wirusem MERS-CoV, który wiąże się do ludzkiej dipeptydylopeptydazy-4 (ang. dipeptidyl peptidase 4, DPP4), a nie ma powinowactwa do mysiej Dpp4. U zainfekowanych MERS-CoV myszy wykazujacych ekspresje DPP4 pod kontrola promotora $K r t 18$, podobnie jak w przypadku myszy Krt18-ACE2 po infekcji SARS-CoV, zaobserwowano zapalenie mózgu. To stanowi wadę modelu. Dlatego za pomoca Crispr/Cas9 stworzono nowy szczep myszy, w którym pełnej długości gen DPP4 wstawiono w locus Rosa26, powodujac globalna ekspresję transgenu. W tym przypadku mRNA Cas9, sgRNA oraz wektor $z$ transgenem zostały wstrzyknięte do mysich zygot. Uzyskany szczep był wysoce podatny na infekcje klinicznym szczepem MERS-CoV, a objawy chorobowe przypominaty przebieg infekcji u ludzi.

\section{MYSZY TRANSDUKOWANE WEKTORAMI AAV}

Esen SEFIK i współaut. (2021, preprint) zaproponowali model będacy modyfikacja humanizowanych myszy MISTRG6. Szczep MISTRG6 to kolejna modyfikacja myszy MISTRG, dodatkowo wykazujaca ekspresję ludzkiej interleukiny 6 (IL-6), która ma poprawiać przyjmowanie się przeszczepów ludzkich komórek krwiotwórczych pochodzacych od dorosłych dawców. Do takich myszy wprowadzono gen kodujacy ludzka konwertazę angiotensyny 2, wykorzystujac $\mathrm{w}$ tym celu wektory AAV, utworzone na bazie wirusów towarzyszacych adenowirusom (ang. adeno-associated viruses, AAV). Wprowadzenie genu ACE2 do płuc myszy MISTRG6 po udanej rekonstytucji ludzkimi komórkami krwiotwórczymi pozwoliło na zakażenie zwierzat wirusem SARS-CoV-2 oraz uzyskanie obrazu choroby podobnego do klinicznego przebiegu infekcji (SEFIK i współaut. 2021, preprint).

Żaden model mysi nie odzwierciedla jednak w pełni różnorodnych objawów zakażenia SARS-CoV-2 obserwowanych u ludzi. Wykorzystanie wektorów AAV lub wektorów adenowirusowych do transdukcji in vivo $\mathrm{i}$ uzyskiwania ekspresji ACE2 jest szybkim i wydajnym podejściem, umożliwiajacym uzyskanie modelu do badań infekcji SARS-CoV-2 u różnych szczepów myszy, $z$ różnym tłem genetycznym (np. C57BL6/J z dominacja odpowiedzi typu Th1 lub BALB/c z dominacja odpowiedzi typu Th2). To niewatpliwa zaleta. Transdukcja jest jednak mało specyficzna i prowadzi do ekspresji ACE2 w różnych typach komórek układu oddechowego. Trudno również kontrolować poziom ekspresji transgenu, przy czym ekspresja ta może być krótkotrwała, zaledwie kilku- lub kilkunastodniowa (MUÑOZ-FONTELA i wspó1aut. 2020).

\section{MODELE MYSIE OPARTE NA MODYFIKACJACH WIRUSA SARS-CoV-2}

Odmiennym podejściem jest tworzenie modelu mysiego dla infekcji wirusowej nie poprzez modyfikacje myszy, ale przez modyfikacje wirusa SARS-CoV-2. Przy tworzeniu takich dopasowanych do myszy wirusów zastosowano dwie strategie.

Pierwsza $z$ nich, zastosowana przez Kuna HUANGA i współaut. (2021) polegała na dziesięciokrotnym pasażowaniu SARS-CoV-2 przez mysie płuca, poprzez kolejne infekcje myszy BALB/c (MUÑOZ-FONTELA i współaut. 2020). Do infekcji donosowej wykorzystywano nadsacze $z$ homogenatów płuc pobranych od zainfekowanych wcześniej zwierzat. Uzyskano w ten sposób dostosowany do myszy szczep wirusa WBP-1, który powoduje ciężkie śródmiaższowe zapalenie płuc i śmierć u myszy Balb/c infekowanych donosowo. Scharakteryzowano również mutacje odpowiedzialne za nabycie przez SARS-CoV-2 zdolności do infekowania myszy. Zmodyfikowany wirus może być wykorzystywany do zakażania różnych szczepów myszy, o różnym tle genetycznym (CHU i współaut. 2021). 
Druga strategia zastosowana została przez Kennetha DinNonA i współaut. (2020). Polegała na analizie struktury białek S kilku koronawirusów zdolnych do infekowania myszy i zaprojektowaniu, a nastepnie wprowadzeniu mutacji do jego domeny wiążącej białko ACE2 takiej, która zwiększała prawdopodobieństwo wiazania białka $\mathrm{S}$ wirusa SARS-CoV-2 do mysiej konwertazy Ace2. Uzyskany wirus został nazwany SARS-CoV-2 MA. Okazało się, że wprowadzone modyfikacje rzeczywiście umożliwiły skuteczne infekowanie myszy, a replikację wirusa w drogach oddechowych zakażonych zwierząt można było wykryć już 24 h po ekspozycji. Przebieg infekcji wykazywał również cechy wspólne $z$ przebiegiem infekcji u ludzi. Tak więc, podobnie jak zakażenie SARS-CoV-2 u ludzi, zakażenie SARS-CoV-2 MA u myszy prowadziło do replikacji wirusa zarówno w górnych, jak i w dolnych drogach oddechowych (DINNON i współaut. 2020). Co więcej, znacznie cięższy przebieg zakażenia obserwowano u myszy starych, co przypomina sytuację w populacji ludzkiej.

Modele zmodyfikowanych wirusów moga być bardzo cenne w badaniach mechanizmów infekcji, interakcji między patogenem a gospodarzem oraz w poznawaniu biologii wirusa. Trzeba natomiast brać pod uwagę, że wprowadzone mutacje moga potencjalnie wpływać na rozpoznawanie wirusa przez specyficzne przeciwciała neutralizujace. Moga więc nie być optymalne do testowania niektórych typów opracowywanych leków (MuÑOZ-FONTELA i współaut. 2020).

\section{MODELE WYKORZYSTUJACE INNE GATUNKI ZWIERZÄT}

Wśród małych zwierząt są gatunki wrażliwe na zakażenie SARS-CoV-2. Najważniejszym potencjalnym modelem badawczym moga być prawdopodobnie chomiki syryjskie (Mesocricetus auratus), które były wykorzystywane między innymi w pracach nad SARS-CoV-1. Porównanie in silico sekwencji ACE2 człowieka $z$ białkiem chomiczym sugerowało, że chomiki syryjskie moga być podatne na infekcje SARS-CoV-2. Przypuszczenie to zostało potwierdzone. Po doświadczalnym zakażeniu donosowym u chomików syryjskich występuje łagodna lub umiarkowana choroba $z$ postępujaca utrata masy ciała i oznakami zaburzeń oddechowych. Po dwóch tygodniach infekcji chomiki zwykle zdrowieja. Podobnie jak u ludzi, stare chomiki i samce rozwijaja cięższe objawy chorobowe. Dochodzi również do zakażania kolejnych zwierząt, dzięki czemu chomiki moga być przydatne w badaniach nad transmisja wirusa. Największą wada tego modelu jest niewielki zestaw narzędzi badawczych, np. specyficznych przeciwciał, które można wykorzystać w analizach (MUÑOz-FONTELA i współaut. 2020).

Innym gatunkiem wrażliwym na zakażenia SARS-CoV-2 sa fretki (Mustela putorius furo). Przebieg choroby zwykle jest łagodny lub umiarkowany, bez wpływu na mase ciała, $z$ niewielkimi zmianami parametrów hematologicznych i podwyższona temperatura. Obserwuje się też wyraźną odpowiedź zapalną (JiA i współaut. 2020). Podobnie jak w przypadku chomików syryjskich, replikacja wirusa $u$ fretek jest wykrywana w drogach oddechowych (głównie górnych) bardzo wcześnie i zanika po około dwóch tygodniach. Może dochodzić do zakażeń między zwierzętami, również droga kropelkową, więc gatunek ten także może być przydatny w badaniach transmisji wirusa (MUÑOZ-FONTELA i współaut. 2020).

SARS-CoV-2 zakaża też norki (Neovison vison), u których przebieg choroby jest zwykle cięższy niż u fretek, $z$ objawami ze strony układu oddechowego, w tym $z$ trudnościami w oddychaniu. Niektóre norki padaja w wyniku infekcji. Norki i fretki sa potencjalnie ciekawymi modelami badawczymi. Jednocześnie jednak sa trudne do utrzymywania w laboratoriach, zwłaszcza $z$ zachowaniem standardów bezpieczeństwa biologicznego BL3. Niewiele jest również narzędzi biologicznych dla tych gatunków, co bardzo ogranicza zakres możliwych do wykonania analiz.

Warto pamiętać, że wrażliwe na zakażenie SARS-CoV-2 sa koty domowe (Felis catus), które w wyniku infekcji moga rozwijać śródmiąższowe zapalenie płuc oraz zapalenie małżowin nosowych i tchawicy, choć infekcja może przebiegać bezobjawowo. Chore koty moga zakażać kolejne osobniki, również droga kropelkową. W znacznie mniejszym stopniu podatne na zakażenia SARS-CoV-2 sa natomiast psy (Canis lupus familiaris), u których infekcja przebiega zwykle bezobjawowo lub bardzo łagodnie.

\section{PODSUMOWANIE}

Wykorzystanie myszy jako systemu modelowego do badań przebiegu infekcji wirusem SARS-CoV-2 wydaje sie optymalnym rozwiazaniem. Dostępnych jest wiele szczepów myszy transgenicznych, $z$ różnym tłem genetycznym, pozwalających na badania różnorodnych aspektów odpowiedzi na zakażenie. Dobrze poznane sa również zależności między genomem a cechami fenotypowymi zwierzat. Do pracy na myszach dysponujemy najbogatszym zestawem przeciwciał, sond i zoptymalizowanych protokołów. Moż- 
liwość właczenia do badań myszy humanizowanych, $z$ funkcjonalnymi komórkami ludzkiego układu odpornościowego, stwarza możliwości bardziej bezpośredniego odnoszenia wyników uzyskanych w układzie modelowym, do przebiegu infekcji u ludzi.

Streszczenie

Myszy sa podstawowym modelem badawczym w biologii i fizjologii. Jednak, aby móc badać na modelach mysich ludzką fizjologię oraz rozwój chorób specyficznych dla ludzi, należało stworzyć nowe ich szczepy. W tym celu opracowano myszy humanizowane, które wykazują ekspresję ludzkich genów albo maja przeszczepione ludzkie tkanki lub komórki. W niniejszej pracy opisujemy przede wszystkim szczepy myszy, w których można utrzymać ludzki układ odpornościowy. Pandemia COVID-19 spowodowała duże zainteresowanie badaczy biologia wirusa SARS-CoV-2. Dlatego w dalszej części artykułu skupiamy się nad modelami zwierzęcymi pozwalającymi badać zakażenie wirusem SARS-CoV-2. Opisujemy modele myszy transgenicznych wykazujacych ekspresję ludzkiego genu ACE2, myszy transgeniczne z ludzkim układem odpornościowym i inne modele zwierzęce wykorzystywane w badaniach nad COVID-19.

\section{LITERATURA}

BILlerbeck E., BARRY W. T., Mu K., DORNER M., RICE C. M. i współaut., 2011. Development of human $C D 4+F O x P 3+$ regulatory $T$ cells in human stem cell factor-, granulocyte-macrophage colony-stimulating factor-, and interleukin-3-expressing NOD-SCID IL2R rnull humanized mice. Blood 117, 3076-3086.

BRYDA E. C., 2013. The Mighty Mouse: The impact of rodents on advances in biomedical research. Missouri Med. 110, 207-211.

Chen L., Ozato K., 2021. Innate immune memory in hematopoietic stem/progenitor cells: myeloidbiased differentiation and the role of interferon. Front. Immunol. 12, doi.org/10.3389/ fimmu.2021.621333.

Chu H., ChAn J. F.-W., 2021. A lethal mouse model using a mouse-adapted SARS-CoV-2 strain with enhanced binding to mouse ACE2 as an important platform for COVID-19 research. EBioMedicine 68, doi.org/10.1016/j.ebiom.2021.103406.

DINNON K. H. 3RD, LEIST S. R., SCHÄFER A., EDWARDS C. E., MARTINEZ D. R., MONTGOMERY S. A. i współaut., 2020. A mouse-adapted model of SARS-CoV-2 to test COVID-19 countermeasures. Nature 586, 560-566.

DouAm F., Ploss A., 2018. The use of humanized mice for studies of viral pathogenesis and immunity. Curr. Opin. Virol. 29, 62-71.

Huang K., Zhang Y., Hui X., ZHAO Y., Gong W. i współaut., 2021. Q493K and Q498H substitutions in Spike promote adaptation of SARS-CoV-2 in mice. EBioMedicine 67, doi. org/10.1016/j.ebiom.2021.103381.

ISHIKAWA F., YASUKAWA M., LYONS B., YOSHIDA S., MiYamoto T. i współaut., 2005. Development of functional human blood and immune systems in NOD/SCID/IL2 receptor Y chain null mice. Blood 106, 1565-1573.

JiA H., Yue X., Lazartigues E., 2020. ACE2 mouse models: A toolbox for cardiovascular and pulmonary research. Nat. Commun. 11, doi: 10.1038/s41467-020-18880-0.
KARpel M. E., Boutwell C. L., Allen T. M., 2015. BLT humanized mice as a small animal model of HIV infection. Curr. Opin. Virol. 13, 75-80.

KowalczyK P., Biata D., SzcZepanik M., MAJEwSKA-SZCZEPANIK M., 2019. Modele myszy $z$ niedoborami odporności: Charakterystyka i zastosowanie. Kosmos 68, 375-387.

LAN P., TONOMURA N., SHIMizU A., WANG S., YANG Y.-G., 2006. Reconstitution of a functional human immune system in immunodeficient mice through combined human fetal thymus/liver and CD34+ cell transplantation. Blood 108, 487-492.

LANDER E. S., Linton L. M., BirRen B., Nusbaum C., Zody M. C. i współaut., 2001. Initial sequencing and analysis of the human genome. Nature 409, 860-921.

LIU F.-L., WU K., SUN J., DUAN Z., QUAN X. i współaut., 2020. Rapid generation of ACE2 humanized inbred mouse model for COVID-19 with tetraploid complementation. Nat. Sci. Rev. 8 doi.org/10.1093/nsr/nwaa285.

MaKinO S., KUNimOto K., MURAOKA Y., MiZUSHIMA Y., KATAGIRI K., TOCHINO Y., 1980. Breeding of a non-obese, diabetic strain of mice. Exp. Anim. 29, 1-13.

McInTOSH B. E., Brown M. E., Duffin B. M., MAUFORT J. P., VEREIDE D. T. i współaut., 2015. Nonirradiated NOD,B6.SCID Il2ry-/Kit(W41/W41) (NBSGW) mice support multilineage engraftment of human hematopoietic cells. Stem Cell Rep. 4, 171-180.

Mestas J., Hughes C. C. W., 2004. Of mice and not men: differences between mouse and human immunology. J. Immunol. 172, 27312738.

Muñoz-Fontela C., Dowling W. E., Funnell S. G. P., GSEll P.-S., Riveros-BAlta A. X. i współaut., 2020. Animal models for COVID-19. Nature 586, 509-515.

Nicolini F. E., CASHMAN J. D., Hogge D. E., HuMPHRIES R. K., EAVES C. J., 2004. NOD/ SCID mice engineered to express human IL-3, GM-CSF and Steel factor constitutively mobilize engrafted human progenitors and compromise human stem cell regeneration. Leukemia 18, 341-347.

Pearson T., Shultz L. D., Miller D., King M., LANING J. i współaut., 2008. Non-obese diabetic-recombination activating gene-1 (NODRag1 null) interleukin (IL)-2 receptor common gamma chain (IL2r gamma null) null mice: A radioresistant model for human lymphohaematopoietic engraftment. Clin. Exp. Immunol. $154,270-284$

Reinisch A., Thomas D., CoRces M. R., Zhang X., GRATZINGER D. i współaut., 2016. A humanized bone marrow ossicle xenotransplantation model enables improved engraftment of healthy and leukemic human hematopoietic cells. Nat. Med. 22, 812-821.

RongVAuX A., Willinger T., MARTINEK J., STROWIG T., Gearty S. V. i współaut., 2014. Development and function of human innate immune cells in a humanized mouse model. Nat. Biotechnol. 32, 364-372.

Sefik E., IsRaelow B., ZhaO J., QU R., SONG E. i współaut., 2021. A humanized mouse model of chronic COVID-19 to evaluate disease mechanisms and treatment options. Res. Sq., doi: 10.21203/rs.3.rs-279341/v1.

Shultz L. D., Lyons B. L., Burzenski L. M., GotT B., CHEN X. i współaut., 2005. Human lymphoid and myeloid cell development in NOD/ 
LtSz-scid IL2R gamma null mice engrafted with mobilized human hemopoietic stem cells. J. Immunol. 174, 6477-6489.

Szade K., Gulati G. S., Chan C. K. F., KaO K. S., MiYANishi M. i współaut., 2018. Where hematopoietic stem cells live: the bone marrow niche. Antioxid. Redox Signal. 29, 191-204.

TAKENAKA K., PRASOlava T. K., WANG J. C. Y., MORTIN-TOTH S. M., Khalouei S. i współaut., 2007. Polymorphism in Sirpa modulates engraftment of human hematopoietic stem cells. Nat. Immunol. 8, 1313-1323.

TAO L., REESE T. A., 2017. Making mouse models that reflect human immune responses. Trends Immunol. 38, 181-193.

Venter J. C., Adams M. D., Myers E. W., Li P. W., Mural R. J. i współaut., 2001. The sequence of the human genome. Science 291, 1304-1351.
WATERSTON R. H., LINDBLAD-TOH K., BIRNEY E., ROGERS J., ABRIL J. F. i współaut., 2002. Initial sequencing and comparative analysis of the mouse genome. Nature, 420, 520-562.

Wunderlich M., ChOU F.-S., LinK K. A., MizuKAWA B., PERRY R. L. i współaut., 2010. AML xenograft efficiency is significantly improved in NOD/SCID-IL2RG mice constitutively expressing human SCF, GM-CSF and IL-3. Leukemia 24, 1785-1788.

Yinda C. K., PORT J. R., Bushmaker T., OFFEI OWUSU I., PURUSHOTHAM i współaut., 2021. K18-hACE2 mice develop respiratory disease resembling severe COVID-19. PLoS Pathogens 17, doi.org/10.1371/journal.ppat.1009195.

ZHENG J., WONG L.-Y. R., LI K., VERMA A. K., ORTIZ M. E. i współaut., 2021. COVID-19 treatments and pathogenesis including anosmia in K18-hACE2 mice. Nature 589, 603-607.

KOSMOS Vol. 70, 3, 485-494, 2021

Witold N. Nowak, IZABella Noworyta, Grzegorz SokoŁowski, Alicua Józkowicz

Department of Medical Biotechnology, Faculty of Biochemistry, Biophysics and Biotechnology, Jagiellonian University, 7 Gronostajowa Str., 30-387 Kraków, Email: alicja.jozkowicz@uj.edu.pl

HUMANIZED MICE AND THEIR USE IN MODELING OF HUMAN INFECTIOUS DISEASES

\section{Summary}

Mice are the primary research model in biology and physiology. However, in order to be able to study human physiology and the development of human-specific diseases in mouse models, new strains had to be created. For this purpose, humanized mice that express human genes or have transplanted human tissues or cells were developed. In this paper, we mainly focus on mouse strains in which the human immune system can be sustained. The COVID-19 pandemic has sparked a lot of interest among researchers in the biology of the SARS-CoV-2 virus. Therefore, later in the article, we focus on animal models that allow studying SARS-CoV-2 infection. We describe transgenic mouse models expressing the human ACE2 gene, transgenic mice with the human immune system, and other animal models used in COVID-19 research.

Key words: animal models, coronavirus, humanization, immunology, transplantation 